\title{
Calcium-dependent cyto- and genotoxicity of nickel metal and nickel oxide nanoparticles in human lung cells
}

Sebastiano Di Bucchianico', Anda R. Gliga', Emma Åkerlund', Sara Skoglund², Inger Odnevall Wallinder², Bengt Fadeel ${ }^{1}$ and Hanna L. Karlsson ${ }^{1 *}$ (D)

\begin{abstract}
Background: Genotoxicity is an important toxicological endpoint due to the link to diseases such as cancer. Therefore, an increased understanding regarding genotoxicity and underlying mechanisms is needed for assessing the risk with exposure to nanoparticles (NPs). The aim of this study was to perform an in-depth investigation regarding the genotoxicity of well-characterized Ni and NiO NPs in human bronchial epithelial BEAS-2B cells and to discern possible mechanisms. Comparisons were made with $\mathrm{NiCl}_{2}$ in order to elucidate effects of ionic $\mathrm{Ni}$.

Methods: BEAS-2B cells were exposed to $\mathrm{Ni}$ and $\mathrm{NiO} \mathrm{NPs}$, as well as $\mathrm{NiCl}_{2}$, and uptake and cellular dose were investigated by transmission electron microscopy (TEM) and inductively coupled plasma mass spectrometry (ICP-MS). The NPs were characterized in terms of surface composition (X-ray photoelectron spectroscopy), agglomeration (photon cross correlation spectroscopy) and nickel release in cell medium (ICP-MS). Cell death (necrosis/apoptosis) was investigated by Annexin VFITC/PI staining and genotoxicity by cytokinesis-block micronucleus (cytome) assay (OECD 487), chromosomal aberration (OECD 473) and comet assay. The involvement of intracellular reactive oxygen species (ROS) and calcium was explored using the fluorescent probes, DCFH-DA and Fluo-4.
\end{abstract}

Results: NPs were efficiently taken up by the BEAS-2B cells. In contrast, no or minor uptake was observed for ionic Ni from $\mathrm{NiCl}_{2}$. Despite differences in uptake, all exposures ( $\mathrm{NiO}, \mathrm{Ni} \mathrm{NPs}$ and $\mathrm{NiCl}_{2}$ ) caused chromosomal damage. Furthermore, $\mathrm{NiO}$ NPs were most potent in causing DNA strand breaks and generating intracellular ROS. An increase in intracellular calcium was observed and modulation of intracellular calcium by using inhibitors and chelators clearly prevented the chromosomal damage. Chelation of iron also protected against induced damage, particularly for $\mathrm{NiO}$ and $\mathrm{NiCl}_{2}$.

Conclusions: This study has revealed chromosomal damage by Ni and NiO NPs as well as Ni ionic species and provides novel evidence for a calcium-dependent mechanism of cyto- and genotoxicity.

Keywords: Nickel/nickel oxide nanoparticles, Chromosomal aberrations, Endoreduplication, Calcium homeostasis, Carcinogenic potential

\section{Background}

Exposure to particles containing nickel $(\mathrm{Ni})$ via inhalation is common at occupational settings such as in nickel refineries, stainless steel production sites and at work places where welding is performed. Furthermore, considerable evidence shows that such exposure increases the risks of both lung fibrosis and cancer in exposed workers

\footnotetext{
* Correspondence: hanna.l.karlsson@ki.se

${ }^{1}$ Institute of Environmental Medicine, Karolinska Institutet, Stockholm,

Sweden

Full list of author information is available at the end of the article
}

$[1,2]$. The International Agency for Research on Cancer has therefore classified nickel compounds as carcinogenic to humans (Group 1) whereas Ni metal, on the other hand, is classified as Group 2B (possibly carcinogenic to humans) [3, 4]. This is due to a lack of associations observed in epidemiological studies and no clear association between respiratory tumors and micron-sized nickel metal powder in a chronic inhalation study on rats [5]. Recently, IARC also concluded that there now is sufficient evidence in humans that welding fumes cause lung cancer [6]. Nickel compounds are categorized as water-soluble or 
water-insoluble (poorly soluble), or alternatively grouped as soluble, sulfidic and oxidic Ni [7]. Indeed, the toxicological profile appears to differ substantially between these groups. When, for example, soluble nickel sulfate $\left(\mathrm{NiSO}_{4}\right)$, green nickel oxide $(\mathrm{NiO})$ and nickel subsulfide $\left(\mathrm{Ni}_{3} \mathrm{~S}_{2}\right)$ were tested in two-year animal inhalation studies, an increase of lung tumors in rats was found for $\mathrm{NiO}$ and $\mathrm{Ni}_{3} \mathrm{~S}_{2}$ (most potent), but not for $\mathrm{NiSO}_{4}$ [8]. One plausible explanation is that soluble $\mathrm{Ni}$ is relatively quickly flushed from the lung tissue and, in addition, the cellular uptake appears to be rather limited, which results in less carcinogenic effects in vivo and in human epidemiologic studies [9]. In contrast, poorly soluble $\mathrm{Ni}$ compounds are able to enter cells by phagocytosis and/or macropinocytosis and the efficiency of the uptake depends on factors such as size, crystalline structure and surface characteristics (charge, shape, etc.) [9]. Once inside cells and in acidified cytoplasmic vacuoles, such Ni-containing particles can dissolve and release nickel ions, and it has been suggested that this intracellular dissolution allows $\mathrm{Ni}$ ions/species to enter the nucleus [10]. This has resulted in a Ni-bioavailability model, which proposes that the bioavailability of released nickel species in the nucleus of epithelial respiratory cells may explain current findings on the carcinogenic potential of nickel-containing particles [11]. This, in turn, depends also on the clearance governing the maximum retained dose. The model was elaborated based on data for micron-sized Ni-containing particles, and its applicability to estimate the carcinogenic potential of Ni-containing nanoparticles (NPs) still remains to be explored. Ni and NiO NPs are manufactured to be used e.g. as catalysts, sensors, antimicrobials and in energy storage devices [12]. The number of humans exposed to manufactured $\mathrm{Ni}$ and $\mathrm{NiO} \mathrm{NPs}$ is likely still limited, but two case reports have indicated severe effects following inhalation [13, 14]. Pronounced inflammatory effects have been observed following exposure to NiO NPs in animal studies $[15,16]$, and several in vivo and in vitro studies have shown NPs to induce more toxicity as compared with micron-sized Ni-containing particles [17-20]. Particle size is, however, not the only parameter governing the detrimental response and nickel release as well as toxicity has also been observed for reactive micron-sized Ni particles [21, 22].

Despite the classification of $\mathrm{Ni}$ compounds as carcinogenic, and Ni metal as possible carcinogenic, the molecular mechanisms leading to lung cancer are not fully elucidated. A wide range of possible mechanisms has been proposed including genotoxicity, effects on DNA repair proteins and epigenetic changes [2,23]. Even though some studies have investigated the ability of $\mathrm{Ni}$ and $\mathrm{NiO}$ NPs to induce DNA strand breaks [22, 24], more in-depth genotoxicity studies are still needed and mechanisms to be elucidated. To this end, the aim of this study was to investigate the ability of
$\mathrm{Ni}$ and $\mathrm{NiO}$ NPs to alter genome stability in human bronchial epithelial BEAS-2B cells and to explore the underlying mechanisms. In particular, we focused on formation of micronucleus and chromosomal aberration, hallmarks of genome instability and predictors of cancer risk, and elucidated the role of oxidative stress as well as calcium and iron homeostasis. The cell uptake/cell dose was analyzed using inductively coupled plasma mass spectrometry (ICP-MS) and comparisons were made with soluble nickel $\left(\mathrm{NiCl}_{2}\right)$ in order to elucidate effects of nanoparticles vs ionic species. We used BEAS-2B cells for several reasons including; 1$)$ they have been suggested to exhibit high similarities in gene expression pattern with primary cells and are therefore regarded a good lung model [25]; 2) they are cultured under serum free conditions that is more relevant for lung cells and could constitute a more sensitive model for NPs [26]; 3) they have been widely used for investigating genotoxic effects of NPs (see e.g. [27]).

\section{Methods \\ Nanoparticles}

Nickel nanopowder $(\mathrm{Ni},<100 \mathrm{~nm}$, purity $>99 \%$, Cat\#: 577995, 93397KJ), nickel (II) oxide nanopowder ( $\mathrm{NiO},<$ $50 \mathrm{~nm},>99.8 \%$ purity, Cat\# 637130, 17198PJ) and water soluble nickel (II) chloride $\left(\mathrm{NiCl}_{2} \cdot 6 \mathrm{H}_{2} \mathrm{O}\right.$, Cat\# N5756, 37H3494) were purchased from Sigma-Aldrich. Size and morphology of the same batch of $\mathrm{Ni}$ and NiO NPs have previously been reported [22] using transmission electron microscopy (TEM) showing Ni NPs to be predominantly less than $100 \mathrm{~nm}$ with a BET-area of $6.41 \mathrm{~m}^{2} / \mathrm{g}$ and the NiO NPs less than $50 \mathrm{~nm}$ and a BET-area of $102 \mathrm{~m}^{2} / \mathrm{g}$. Particle dispersions were freshly prepared in cell medium $(1 \mathrm{mg} / \mathrm{mL})$ followed by $15 \mathrm{~min}$ sonication in an ultrasonic bath (Branson 2200). Subsequent dilutions were immediately prepared in cell medium prior to exposure. Previous modelling of speciation of released ions in cell medium showed that $\mathrm{Ni}$ ions form strong complexes with amino acids and are not present as free ions or labile complexes [22].

\section{Surface analysis using XPS}

X-ray photoelectron spectroscopy (XPS, UltraDLD spectrometer, Kratos Analytical, Manchester, UK) was utilized in order to characterize the outermost surface of $\mathrm{Ni}$ and $\mathrm{NiO}$ nano. High resolution spectra $(20 \mathrm{eV})$ were acquired using a monochromatic $\mathrm{Al} \mathrm{K \alpha}$-source (1486.6 eV, $300 \mathrm{~W})$. Charge corrections were made to $\mathrm{C} 1 \mathrm{~s}$ at $285.0 \mathrm{eV}$.

\section{Cell culture and exposures}

The immortalized human bronchial epithelial cell line (BEAS-2B, European Collection of Cell Cultures) was cultured in supplemented bronchial epithelial cell growth medium (BEGM, Lonza) on pre-coated flasks according to previously described [28]. It is noted that BEGM is 
serum-free and specially designed to support the growth of bronchial epithelial cells. BEAS-2B cells were independently authenticated according to ISO 9001-2004 and Mycoplasma tested (Leibniz Institute DSMZ, Germany). BEAS-2B cells were seeded in 6- or 24-well plates at an approximate density of $5 \times 10^{4}$ cells $/ \mathrm{cm}^{2}$. After $24 \mathrm{~h}$, particle dispersions were directly added to the cell cultures to obtain a final mass concentration of 1,5 and $10 \mu \mathrm{g} / \mathrm{mL}$ based on mass of nickel, corresponding to $0.21,1.05$ and $2.1 \mu \mathrm{g} \mathrm{Ni} / \mathrm{cm}^{2}$. The final volume used in 6- or 24-well plates was $2 \mathrm{~mL}$ and $0.4 \mathrm{~mL}$, respectively, in order to maintain the same $\mu \mathrm{g} / \mathrm{cm}^{2}$ between exposures. The doses were selected mainly based on cytotoxicity with the intention to use doses that were non-cytotoxic or showing effects of maximum around 30\% cytotoxicity. According to the OECD guideline for in vitro $\mathrm{MN}$ assay (487), care should be taken not to exceed $60 \%$ cytotoxicity because higher levels may induce micronuclei as a secondary effect of cytotoxicity.

\section{PCCS analysis}

Dynamic light scattering using photon cross-correlation spectroscopy (PCCS) (NanoPhox, Sympatec, Germany) was used to determine the hydrodynamic size of the NPs $(10 \mu \mathrm{g} / \mathrm{mL})$ in cell medium. In brief, $1 \mathrm{~mL}$ dispersions of $\mathrm{Ni}$ and $\mathrm{NiO}(10 \mu \mathrm{g} / \mathrm{mL})$ were prepared in cuvettes and analyzed directly after dispersion $(0 \mathrm{~h})$, after 2 and $24 \mathrm{~h}$. Triplicate samples were analyzed to identify the size distribution pattern and data is presented based on single sample analysis measured three times each. Calibration was made using standard latex samples $(20 \pm 2 \mathrm{~nm})$ and blank samples were analyzed prior to all measurements [28].

\section{TEM analysis}

TEM imaging was performed as previously described [28]. In brief, BEAS-2B cells were exposed to $10 \mu \mathrm{g} \mathrm{Ni} / \mathrm{mL}$ for $48 \mathrm{~h}$. They were then washed, harvested, centrifuged and fixed in freshly prepared $0.1 \mathrm{M}$ glutaraldehyde solution. The pellets were then post fixed in $2 \%$ osmium tetroxide. Ultrathin sections (approximately 60-80 nm) were cut and contrasted with uranyl acetate followed by lead citrate. Samples were then examined using a FEI Tecnai 12 Spirit Bio TWIN transmission electron microscope at $100 \mathrm{kV}$.

\section{ICP-MS analysis}

The cellular uptake and Ni release from the particles in cell medium was quantified using inductively coupled plasma mass spectrometry (ICP-MS). For cellular uptake studies, BEAS-2B cells were seeded in 6-well plates as previously described and exposed to $\mathrm{Ni}, \mathrm{NiO}$ and $\mathrm{NiCl}_{2}$ at the following concentrations and time points: $10 \mu \mathrm{g} \mathrm{Ni} / \mathrm{mL}$ for $4 \mathrm{~h} ; 10 \mu \mathrm{g} \mathrm{Ni} / \mathrm{mL}$ for $24 \mathrm{~h} ; 1,5,10 \mu \mathrm{g} \mathrm{Ni} / \mathrm{mL}$ for $48 \mathrm{~h}$. At the end of the exposure the cells were washed two times with PBS, harvested and counted. For Ni release in cell medium, $\mathrm{Ni}$ and $\mathrm{NiO}$ NPs were incubated with BEGM cell medium for $48 \mathrm{~h}$, at $37{ }^{\circ} \mathrm{C}$. After incubation, the particle dispersions were centrifuged at 13,000 rpm, $1 \mathrm{~h}$ $\left(0{ }^{\circ} \mathrm{C}\right)$ and the supernatants were carefully collected. Non-centrifuged dispersions were also collected in order to measure the amount of $\mathrm{Ni}$ added. All samples (ion release, cellular uptake) were acidified in $32 \% \mathrm{HNO}_{3}$ for at least $48 \mathrm{~h}$. Thereafter the samples were diluted to reach approximately $2 \% \mathrm{HNO}_{3}$. For all samples ${ }^{58} \mathrm{Ni}$ and ${ }^{60} \mathrm{Ni}$ isotopes were quantified using an iCAP Q ICP-MS (Thermo Scientific) instrument in KED mode. Calibration standards of $1,5,10,50,100,500 \mu \mathrm{g} / \mathrm{L}$ Ni were prepared using a 1000 ppm reference standard (Spectrascan). Samples spiked with $5 \mu \mathrm{g} / \mathrm{L}$ indium were used as an internal standard with a range of recovery between 80 and $105 \%$. Each sample was injected at least 3 times and the RSD acceptance was set at $15 \%$. Cell uptake results were normalized according to the cell number and expressed as pg Ni/cell considering the average values of the analyzed isotopes. Nickel release was expressed as percentage $\mathrm{Ni}$ released in cell medium in relation to the amount of added $\mathrm{Ni}$, based on the average values of the analyzed isotopes. The limits of detection for the investigated isotopes were calculated from the SD of the untreated control $(3 \mathrm{x}$ $\mathrm{SD}$ of control) and estimated as $<0.013 \mu \mathrm{g} / \mathrm{L}\left({ }^{58} \mathrm{Ni}\right),<$ $0.008 \mu \mathrm{g} / \mathrm{L}\left({ }^{60} \mathrm{Ni}\right)$ for the cellular uptake experiments and $<0.012 \mu \mathrm{g} / \mathrm{L}\left({ }^{58} \mathrm{Ni}\right),<0.020 \mu \mathrm{g} / \mathrm{L}\left({ }^{60} \mathrm{Ni}\right)$ for the nickel release experiments.

\section{Annexin V-FITC/PI analysis}

The annexin V-FITC/propidium iodide (PI) kit (Calbiochem) was used following the manufacturer's instructions for detection of apoptosis and necrosis [29]. BEAS-2B cells were exposed in 6-well plates to 1, 5 and $10 \mu \mathrm{g} \mathrm{Ni} / \mathrm{mL}$ of $\mathrm{Ni}, \mathrm{NiO} \mathrm{NPs}$ and $\mathrm{NiCl}_{2}$ for $48 \mathrm{~h}$. Live, apoptotic and necrotic cells were detected with a $\mathrm{BD}$ Accuri $^{\text {Tw }}$ C6 Cytometer (BD Biosciences) and twenty thousand events were collected and analyzed with the BD Accuri ${ }^{\text {Tw }}$ software template. Cell debris was gated out before analysis based on light-scattering properties. Untreated cells and $0.2 \mu \mathrm{g} / \mathrm{mL}$ etoposide (Sigma-Aldrich) were used as negative and positive controls.

\section{Comet assay}

DNA damage (single and double DNA strand breaks, and alkali labile sites) was evaluated by the alkaline version $(\mathrm{pH}>13)$ of comet assay. BEAS-2B cells were seeded in 24-well plates and exposed for $48 \mathrm{~h}$ after which the comet assay was performed as described in [28]. Untreated cells were used as negative control and cells treated with $25 \mu \mathrm{M}$ $\mathrm{H}_{2} \mathrm{O}_{2}$ (Sigma-Aldrich) for $10 \mathrm{~min}$ on ice as positive control. 


\section{Intrinsic and intracellular ROS}

The 2', $7^{\prime}$-dichlorodihydrofluorescein diacetate (DCFH-DA) assay was used to measure intrinsic and intracellular ROS production similar as previously described [24]. In short, the intrinsic ROS production was measured by first cleaving the diacetate using $\mathrm{NaOH}$. After neutralization, the $\mathrm{Ni}$ was added in final concentrations of 10,25 and $50 \mu \mathrm{g} \mathrm{Ni} / \mathrm{mL}$ in a black 96 well plate with or without HRP (horseradish peroxidase, final concentration $2.2 \mathrm{U} / \mathrm{mL}$ ). Fluorescence was then measured (excitation $485 \mathrm{~nm}$, emission $535 \mathrm{~nm}$ ) using a plate reader (Tecan Infinite F200). For the intracellular ROS, BEAS-2B cells were seeded in black 96-well plates with transparent bottom and were after $24 \mathrm{~h}$ loaded with $20 \mu \mathrm{M}$ DCFH-DA in HBSS (Hank's buffered salt solution) for $30 \mathrm{~min}$ at $37^{\circ} \mathrm{C}$. Subsequently, cells were washed with HBSS and exposed to 1,5 and $10 \mu \mathrm{g} \mathrm{Ni} / \mathrm{mL}$ of Ni, $\mathrm{NiO} \mathrm{NPs}$ and $\mathrm{NiCl}_{2}$. Tert-butyl hydroperoxide (TBP, 10 and $30 \mu \mathrm{M})$ was used as positive control. Fluorescence was recorded every $5 \mathrm{~min}$ over $2 \mathrm{~h}$ (excitation $485 \mathrm{~nm}$, emission $535 \mathrm{~nm}$ ) using a plate reader (Tecan Infinite F200) at $37^{\circ} \mathrm{C}$ and ROS increase was calculated as mean slope per min and normalized to the unexposed control. Results are presented as mean values \pm standard error of mean (SEM) of three independent experiments.

\section{Intracellular calcium}

BEAS-2B cells were seeded in 6-well plates and exposed to $5 \mu \mathrm{g} \mathrm{Ni} / \mathrm{mL}$ of $\mathrm{Ni}, \mathrm{NiO} \mathrm{NPs}$ and $\mathrm{NiCl}_{2}$ for $2 \mathrm{~h}$. The cells were then washed twice in $\mathrm{Ca} / \mathrm{Mg}$ free HBSS (Gibco) and incubated with $5 \mu \mathrm{M}$ Fluo-4-acetoxymethyl ester (Fluo-4 AM, ThermoFicher Scientific, in 3\% DMSO) in $\mathrm{Ca} / \mathrm{Mg}$ free $\mathrm{HBSS}$ at $37^{\circ} \mathrm{C}$ for $30 \mathrm{~min}$. The cells were then washed twice in HBSS and detached from the plates using $\mathrm{Ca} / \mathrm{Mg}$ free cell dissociation buffer (Gibco) for $30 \mathrm{~min}$ at $37^{\circ} \mathrm{C}$. The cells were then immediately analyzed with the flow cytometer BD Accuri C6 (BD Biosciences) using the $530 / 30$ filter. The fluorescence in 10,000 cells/sample was recorded and addition of $2.5 \mu \mathrm{M}$ calcium ionophore A23187 (in DMSO, Sigma-Aldrich) was used as a positive control. Data analysis was performed using the BD Accuri C6 software and the median fluorescence of each sample was recorded. Results are presented as mean values \pm SEM of three independent experiments. Student's t-test was used to analyze difference between control and exposed cells.

\section{Micronucleus assay}

Cytotoxicity, cytostasis and chromosomal damage were studied by cytokinesis-block micronucleus cytome assay (CBMN Cyt) (OECD 487). BEAS-2B cells were exposed and after $20 \mathrm{~h}, 5 \mu \mathrm{g} / \mathrm{mL}$ cytochalasin-B (Sigma-Aldrich) was used to block cytokinesis in a delayed co-treatment. Cells were harvested after additional $28 \mathrm{~h}$ culture $(48 \mathrm{~h}$ exposure), treated $1 \mathrm{~min}$ with $0.075 \mathrm{M} \mathrm{KCl}$ (hypotonic solution), washed twice with fresh cold fixative (methanol:acetic acid 6:1) and placed at $-20^{\circ} \mathrm{C}$ overnight. The cell solutions were placed onto clean and cold glass slides and the air-dried slides were stained with $4 \%(v / v)$ Giemsa solution (Sigma-Aldrich) in deionized water for $20 \mathrm{~min}$. Untreated cells and $0.05 \mu \mathrm{g} / \mathrm{mL}$ mitomycin C (MMC, Sigma-Aldrich) were used as negative and positive controls. The samples were then scored as previously described [30, 31]. In short, 500 cells per slide were scored to evaluate cytostasis (replication index, RI) and the number of apoptotic, necrotic, and mitotic cells. The genotoxic potential of particle dispersions was evaluated by scoring the micronucleus frequency as number of 1000 binucleated cells containing one or more micronuclei (MN) per slide. The MN frequency in 1000 mononucleated cells was also considered in order to distinguish between aneuploidogenic and clastogenic effects [32]. Finally, nucleoplasmic bridges (NPB), a biomarker of DNA misrepair and/or telomere end-fusions, and nuclear buds (NBUD), a biomarker of elimination of amplified DNA and/or DNA repair complexes, were also scored in 1000 binucleated cells. Two slides per condition were examined in three independent experiments.

\section{Role of calcium and iron}

To investigate the role of intracellular calcium and iron for the induction of MN, NPB, NBUD and cell death, cells were pretreated for $15 \mathrm{~min}$ with either $10 \mu \mathrm{M}$ deferoxamine (Sigma-Aldrich), $5 \mu \mathrm{M}$ verapamil (Sigma-Aldrich), $5 \mu \mathrm{M}$ dantrolene (Sigma-Aldrich), or $0.1 \mu \mathrm{M}$ BAPTA-AM (Molecular Probes, Life Technologies) and then co-exposed $48 \mathrm{~h}$ to $5 \mu \mathrm{g} \mathrm{Ni} / \mathrm{mL}$ of $\mathrm{Ni} / \mathrm{NiO} \mathrm{NPs}$ or $\mathrm{NiCl}_{2}$. The concentrations of chelators/inhibitors were chosen based on previous cell viability experiments in order to avoid cytotoxic conditions.

\section{Chromosomal aberration assay}

Structural aberrations at chromatid and/or chromosome level were assessed by chromosomal aberration assay (OECD 473). BEAS-2B cells were seeded in 6-well plates. After $24 \mathrm{~h}$, particles dispersions were directly added to the cell culture for $48 \mathrm{~h}$ at the final mass concentration of $5 \mu \mathrm{g}$ $\mathrm{Ni} / \mathrm{mL}$. Untreated cells and $0.05 \mu \mathrm{g} / \mathrm{mL}$ MMC were used as negative and positive controls. In the last $3 \mathrm{~h}$ of cultures, $0.05 \mu \mathrm{g} / \mathrm{mL}$ demecolcine (Sigma-Aldrich) was added and cells were harvested, treated $5 \mathrm{~min}$ by $0.075 \mathrm{M} \mathrm{KCl}$ and washed three times with fresh cold fixative (methanol:acetic acid 3:1) and placed at $-20{ }^{\circ} \mathrm{C}$ overnight. Finally, cell suspensions were dropped onto clean and cold glass slides. The air-dried slides were stained with $4 \%(v / v)$ Giemsa solution (Sigma-Aldrich) in Sørensen's buffer ( $\mathrm{pH}$ 7.0) for $6 \mathrm{~min}$. Chromosomal aberrations (CAs) were analyzed as described previously by Nymark et al. [33]. 


\section{Statistical analysis}

Statistical analysis was performed using GraphPad Prism 5 statistical software (GraphPad Inc.). One-way analysis of variance followed by Bonferroni's multiple comparison test was used to test for significance between exposures and results are expressed as mean values \pm standard error of mean (SEM) of three independent experiments $(n=3)$.

\section{Results}

\section{Size, surface analysis and intrinsic ROS generation}

In addition to the information from the manufacturer and our own characterization in previous studied [22, 24], we made new analyses to characterize the NPs. The TEM analysis showed Ni NPs to be of varying sizes but predominantly less than $100 \mathrm{~nm}$, and NiO NPs less than $50 \mathrm{~nm}$ (Fig. 1a). Surface analysis using XPS showed for NiO NPs multiple split peaks of oxidized nickel at $853.7 \pm 0.2$ and $855.8 \pm 0.2 \mathrm{eV}(\mathrm{Ni} 2 \mathrm{p} 3 / 2)$ combined with characteristic satellite peaks and a sharp oxygen peak at $529.7 \pm 0.2 \mathrm{eV}$ (O $1 \mathrm{~s})$ that correlate very well with literature findings for $\mathrm{NiO}[34,35]$. A metallic nickel signal $(852.6 \pm 0.1 \mathrm{eV})$ was evident on Ni NPs in addition to oxidized nickel (855.0 \pm
$0.2 \mathrm{eV}$ ) and satellite peaks that could be assigned to $\mathrm{Ni}$ $(\mathrm{OH}) 2$ (main $\mathrm{O} 1 \mathrm{~s}$ peak at $530.0 \pm 0.2 \mathrm{eV}$ ) $[34,35]$. The results clearly show the presence of a thin $(<5 \mathrm{~nm})$ nickel (II)-rich surface oxide on metallic nickel. Fitted XPS spectra of the NPs are presented in Fig. 1b. To analyze the reactivity of the NPs, we tested the intrinsic ROS generating ability using the DCFH assay. The results showed $\mathrm{NiO}$ NPs to be highly reactive when the assay was performed without HRP whereas $\mathrm{Ni}$ and $\mathrm{NiO}$ showed rather similar (and much less) effects in the presence of HRP. No effects were observed for the $\mathrm{NiCl}_{2}$ (Fig. 1c).

\section{Rapid NP agglomeration and limited nickel release in serum-free cell culture medium}

In order to characterize the behavior of the NPs in cell medium (BEGM), we analyzed the hydrodynamic size and light scattering using photon cross-correlation spectroscopy (PCCS) as well as the dissolution $/ \mathrm{Ni}$ release by means of ICP-MS. The hydrodynamic size measurements in solution (density distributions multiplied with corresponding scattered light intensities) showed that both $\mathrm{Ni}$ and $\mathrm{NiO} \mathrm{NPs}$ agglomerate directly

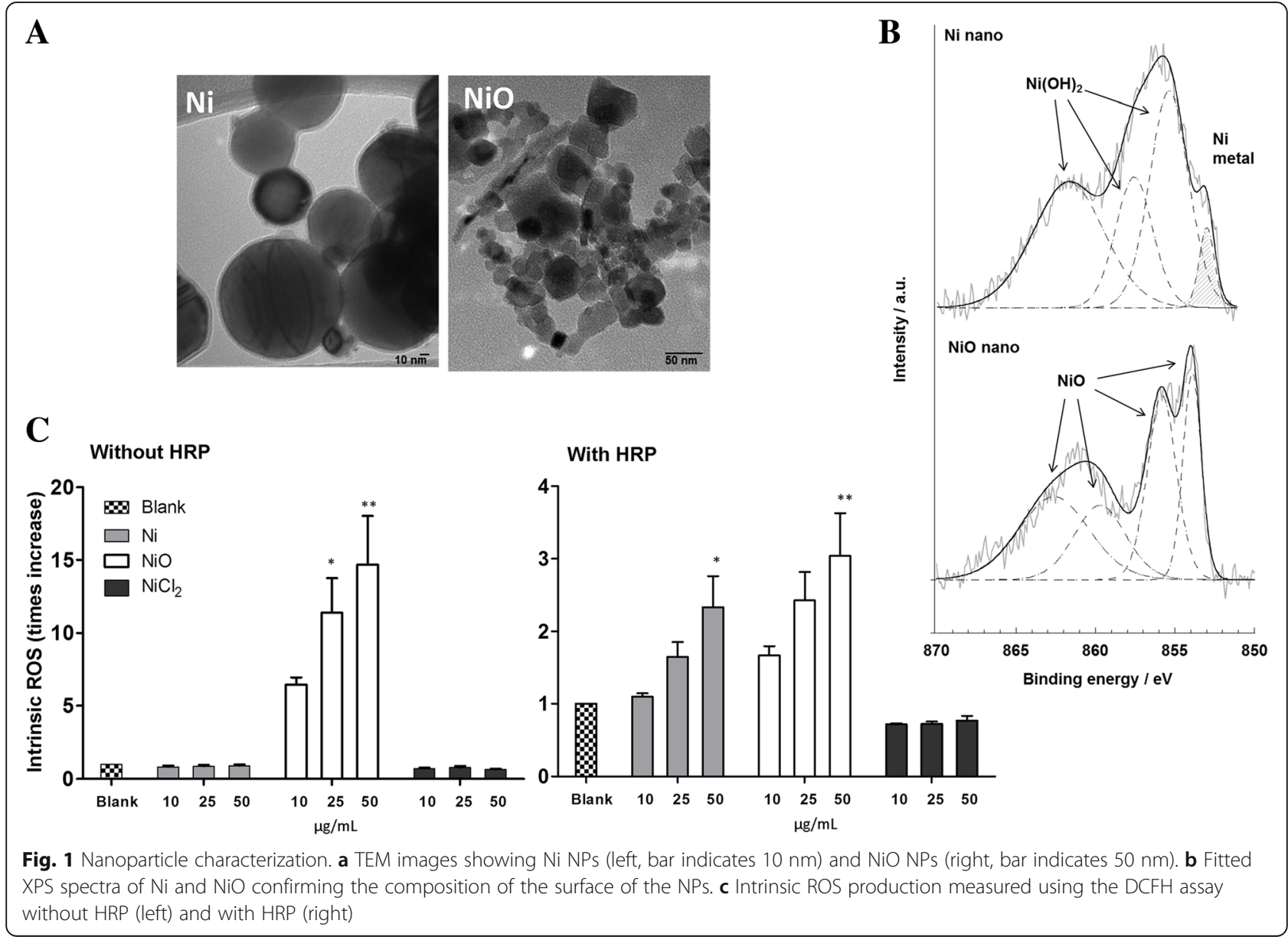


upon dispersion $(0 \mathrm{~h})$ in cell medium (BEGM), with an approximate average agglomerate size of $500 \mathrm{~nm}$ for the Ni NPs and $750 \mathrm{~nm}$ for NiO NPs (Fig. 2a). Negligible scattered light intensity was observed from the BEGM medium alone compared with intensities observed from solutions containing NPs. Signals and size distributions of the NP-containing samples were after 2 and $24 \mathrm{~h}$ of exposure similar to the BEGM medium, findings which indicate particle removal from solution by means of sedimentation. Significantly reduced scattered light intensities with time were observed for both the Ni and the NiO NPs (Fig. 2b). Following incubation with cell medium at $37^{\circ} \mathrm{C}(10 \mu \mathrm{g} \mathrm{Ni} / \mathrm{mL})$ more $\mathrm{Ni}$ in solution (normalized to the total amount of added $\mathrm{Ni}$ ) was determined for NiO NPs compared to Ni NPs at the tested time points $4 \mathrm{~h}, 24 \mathrm{~h}$ and $48 \mathrm{~h}$ (Fig. 2c). An increased amount of released $\mathrm{Ni}$ in solution (based on nickel content) was observed with time reaching levels of approx. 5\% for the Ni NPs and 9\% for the NiO NPs after 48 h. No significant differences were observed between the two NPs in terms of Ni release in solution after $48 \mathrm{~h}$ for the lower particle concentrations (1 and $5 \mu \mathrm{g} \mathrm{Ni} / \mathrm{mL}$ ).

\section{$\mathrm{Ni}$ and NiO NPs, but not ionic nickel species, are readily taken up by human lung cells}

To study cellular uptake and intracellular localization, TEM imaging as well as ICP-MS was conducted. TEM clearly showed that both $\mathrm{Ni}$ and $\mathrm{NiO} \mathrm{NPs}$ were taken up by BEAS-2B cells and were contained within membrane-bound structures (Fig. 3a-d). Vacuoles reminiscent of autophagosomes and early autophagosomes evidenced by rough endoplasmic reticulum surrounding mitochondria were observed following exposure to both $\mathrm{NPs}$ as well as $\mathrm{NiCl}_{2}$. Exposure to $\mathrm{Ni}$ and $\mathrm{NiO} \mathrm{NPs}$ rapidly increased the Ni cellular content as assessed by ICP-MS $4 \mathrm{~h}$ after exposure, reaching $40 / 60 \mu \mathrm{g}$ of $\mathrm{Ni}$ per $10^{6}$ cells (thus higher total mass of $\mathrm{NiO}$ compared to $\mathrm{Ni}$ ) following $48 \mathrm{~h}$ treatments whereas $\mathrm{NiCl}_{2}$ was not significantly taken up by BEAS-2B cells (Fig. 3e). The cell-associated Ni content increased with increasing mass concentrations of $\mathrm{Ni}$ and NiO NPs (Fig. 3f).
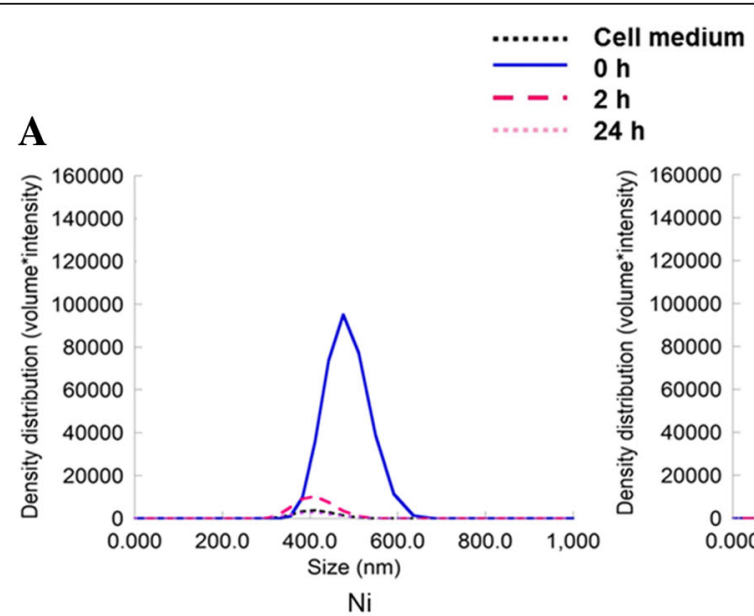

B

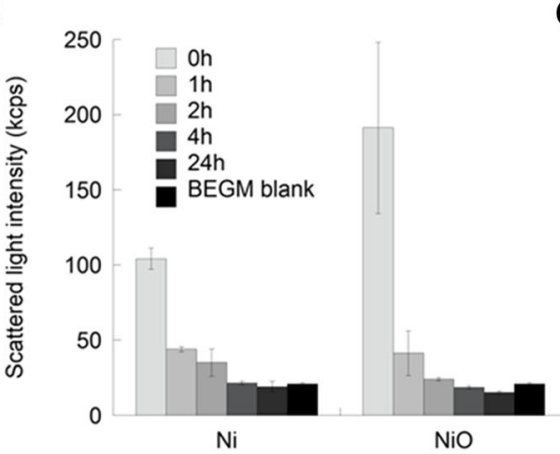

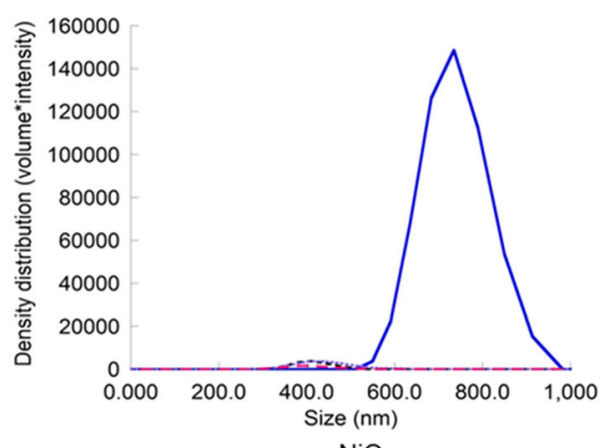

C

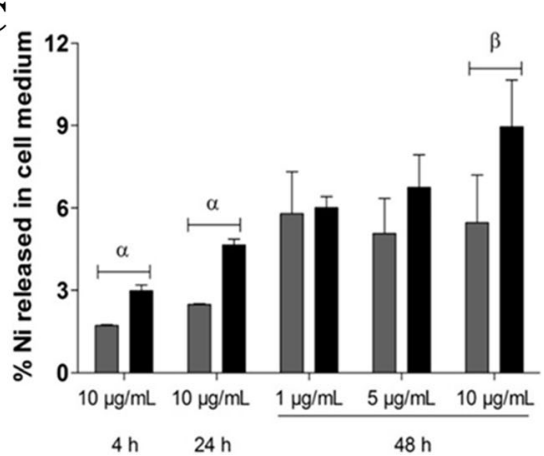

Fig. 2 Nanoparticle characterization in cell medium. Nanoparticle behavior in cell medium (BEGM) was examined by photon cross-correlation spectroscopy (PCCS) and inductively coupled plasma mass spectrometry (ICP-MS). a The PCCS density distribution histograms are presented as density distribution by volume multiplied with corresponding scattered light intensities and indicate the hydrodynamic size distribution of the particles directly after dispersion (0 h), after $2 \mathrm{~h}$, as well as $24 \mathrm{~h}$ at a concentration of $10 \mu \mathrm{g} / \mathrm{mL}$, and (b) corresponding PCCS scattered light intensities. c The amount of Ni released in cell medium after 4, 24 and $48 \mathrm{~h}$ was determined by ICP-MS and expressed as \% Ni released in cell medium from the total amount of added $\mathrm{Ni}$ (determined experimentally) for $\mathrm{Ni}$ (gray) and $\mathrm{NiO}$ (black) 

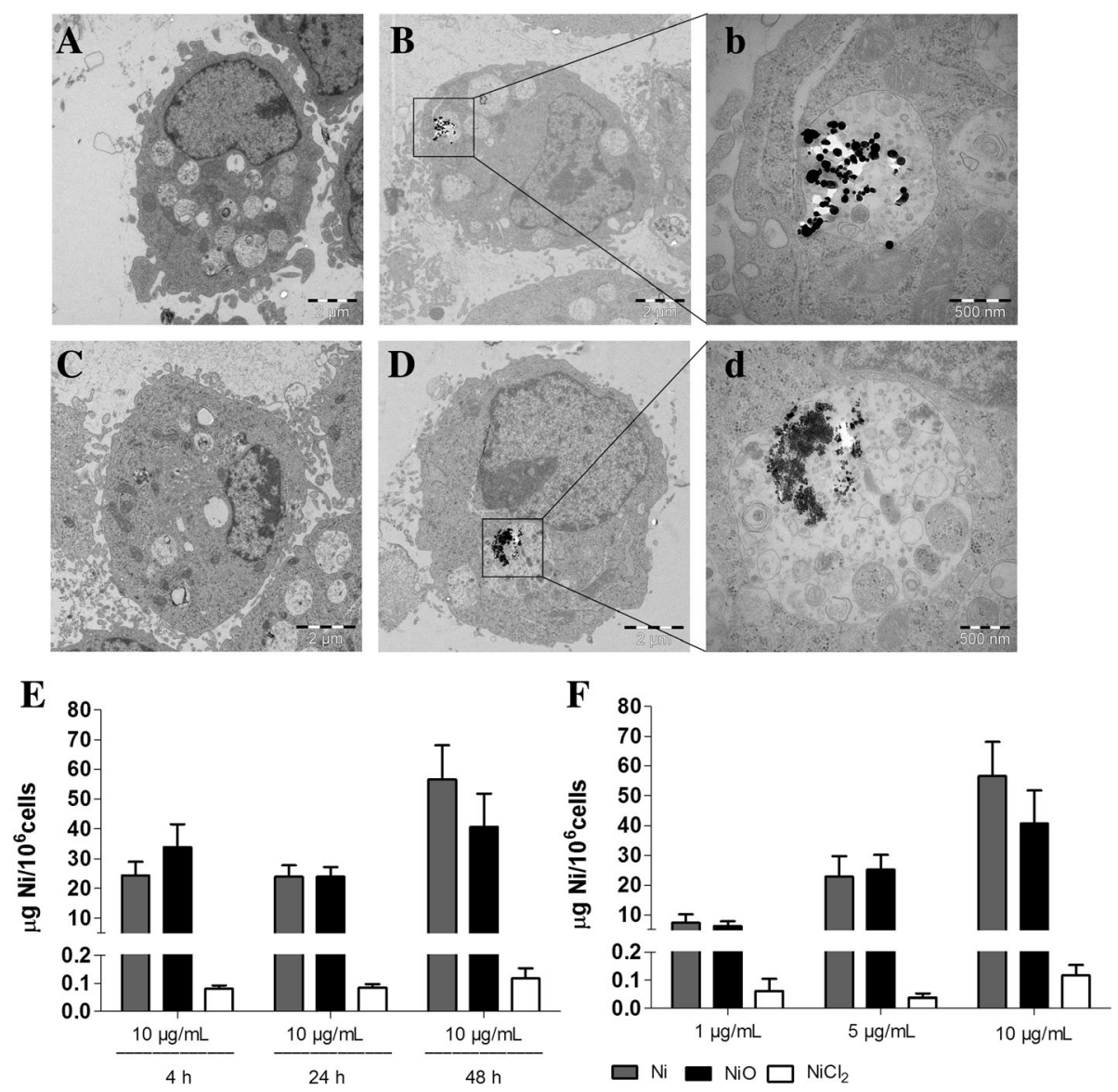

Fig. 3 Intracellular localization and uptake. Cellular ultrastructural alteration and intracellular localization of Ni and NiO NPs in BEAS-2B cells was investigated by TEM (a, control cell; $\mathbf{b}$ with corresponding inserts $\mathbf{b}$, Ni treated cell; $\mathbf{c} \mathrm{NiCl}_{2}$ exposed cell; $\mathbf{d}$ with corresponding inserts $\mathbf{d}$, NiO treated cell). After $48 \mathrm{~h}$ exposure to $10 \mu \mathrm{g} \mathrm{Ni} / \mathrm{mL}$ of Ni (b) and NiO NPs (d), particles were taken up and contained within membrane-bound structures (b and $\mathbf{d}$ ). The time-dependent cellular Ni content was investigated by ICP-MS after $10 \mathrm{\mu g} \mathrm{Ni/mL} \mathrm{(4} \mathrm{h,} 24 \mathrm{~h}$ and 48 h) exposures (e) whereas the concentration-dependent uptake was studied following 1,5 and $10 \mu \mathrm{g} \mathrm{Ni} / \mathrm{mL}$ (48 h) exposures to Ni, $\mathrm{NiO}$ and $\mathrm{NiCl}_{2}$

\section{NiO NPs induce more apoptosis in BEAS-2B cells} compared to Ni NPs and ionic Ni

To obtain a comprehensive view of the cytotoxic/cytostatic effects of the different exposures, we performed annexin V/PI staining (necrosis/apoptosis) and scoring of cells microscopically (as performed in the CBMN Cyt assay). Following $\mathrm{Ni}$ and $\mathrm{NiO} \mathrm{NP}$ exposures, the percentage of apoptotic cells increased in a dose-dependent manner and $\mathrm{NiO}$ was clearly most effective leading to approx. 25\% apoptotic cells in the highest concentration $(10 \mu \mathrm{g} \mathrm{Ni} / \mathrm{mL})$ (Fig. 4a). The fraction of necrotic cells also increased particularly in the highest concentration $\left(10 \mu \mathrm{g} \mathrm{Ni} / \mathrm{mL}\right.$ ) of $\mathrm{NiO} \mathrm{NPs}$ and $\mathrm{NiCl}_{2}$ (Fig. 4b). The same trend regarding apoptosis and necrosis was also observed from cells scored microscopically in the CBMN Cyt assay (Additional file 1: Figure S1). The microscopic analysis also showed, interestingly, that the lowest concentration of Ni NPs increased the replication index when compared to the control (Fig. 4c). In contrast, $10 \mu \mathrm{g} \mathrm{Ni} / \mathrm{mL}$ of $\mathrm{NiO} \mathrm{NPs}$ and $\mathrm{NiCl}_{2}$ showed a significant cytostatic effect (Fig. 4c) and also reduced the mitotic index (Fig. 4d). Taken together, the data showed $\mathrm{NiO}$ NPs to be more cytotoxic compared to Ni NPs. Furthermore, a low dose of Ni NPs was found to increase cell replication.

NiO NPs cause more DNA strand breaks, intracellular ROS and $\mathrm{Ca}^{2+}$ compared to Ni NPs and ionic $\mathrm{Ni}$

Next, we investigated the ability to cause DNA strand breaks (comet assay) and intracellular ROS formation (DCFH-DA assay). All exposures increased the DNA damage compared to control and $\mathrm{NiO}$ was the most potent causing $>3$ times increase in DNA damage in the two highest doses (Fig. 4b). $\mathrm{Ni}$ and $\mathrm{NiCl}_{2}$ caused modest effects without clear dose-response. NiO NPs were also the most potent inducer of intracellular ROS with a 


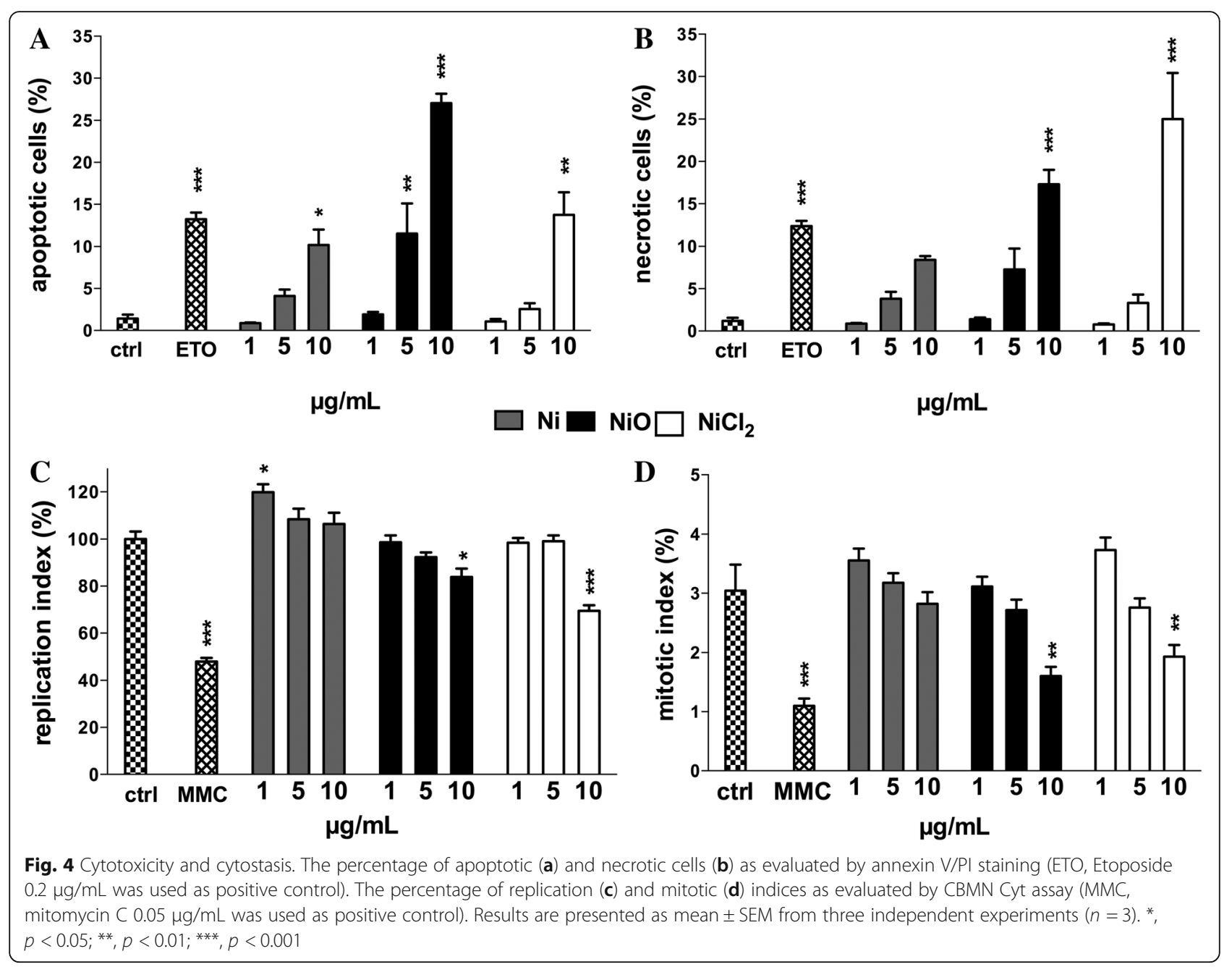

significant increase in all doses tested (Fig. 5a). Increased levels were also noted for $\mathrm{NiCl}_{2}$ but not for Ni NPs. Similarly, $\mathrm{NiO} \mathrm{NPs}$ and $\mathrm{NiCl}_{2}$ caused a statistically significant increase in intracellular $\mathrm{Ca}^{2+}$, whereas $\mathrm{Ni} \mathrm{NPs}$ showed more variation among the experiments leading to a non-significant increase (Fig. 5c).

\section{All Ni exposures cause chromosomal damage and rearrangements}

In order to acquire more in-depth insight into genotoxicity, we analyzed the frequency of micronuclei $(\mathrm{MN})$, nucleoplasmic bridges (NPB), a biomarker of DNA misrepair and/or telomere end-fusions, nuclear buds (NBUD), a biomarker of elimination of amplified DNA and/or DNA repair complexes as well as chromosomal aberrations according to OECD accepted protocols (OECD 487, OECD 473). The frequency of $\mathrm{MN}$ in binucleated cells was significantly higher compared to control cells for the two highest concentrations tested for all three $\mathrm{Ni}$ exposures. $\mathrm{NiO}$ NPs were most potent causing approx. $3 \% \mathrm{MN}$ in binucleated cells compared to $1 \%$ in the control (Fig. 6a). $\mathrm{Ni} \mathrm{NPs}$ and $\mathrm{NiCl}_{2}$ were more effective than $\mathrm{NiO}$ NPs in inducing micronuclei in mononucleated cells, indicating aneuploidogenic activity (Fig. 6b). Similarly, Ni NPs and $\mathrm{NiCl}_{2}$ increased NPB and NBUD frequencies to a higher extent as compared with $\mathrm{NiO}$ NPs (Fig. 6c and d). Analysis of chromosomal aberrations showed that Ni NPs and $\mathrm{NiCl}_{2}$ significantly increased the rate of chromatid-type aberrations and induced both inter- and intra-arm exchanges (See Additional file 1: Table S1). All treatments induced chromosome-type aberrations and NiO NPs were the most effective in inducing chromosome breaks and acentric fragments whereas $\mathrm{Ni} \mathrm{NPs}$ and $\mathrm{NiCl}_{2}$ were the most potent in inducing the formation of dicentric chromosomes as well as endo-reduplications (duplication of nuclear genome in the absence of cell division) (See Additional file 1: Table S1 and Figure S2). Untreated BEAS-2B cells showed a modal chromosome number $(45.9 \pm 0.6)$ whereas all exposures induced various degree of ploidy such as trisomy, and to a lesser extent 


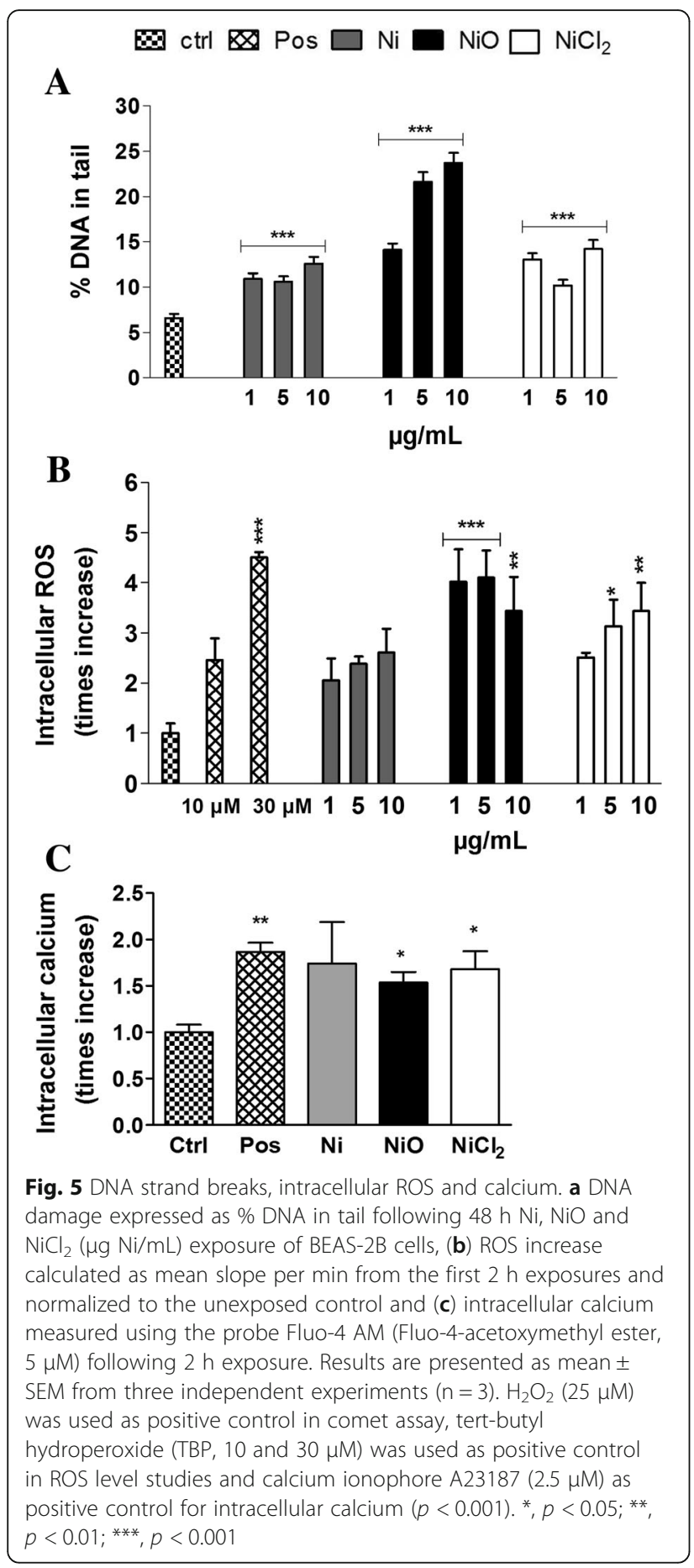

monosomy, involving particularly chromosomes $1,3,14$, 20 and 21. The mitotic index was slightly increased in $\mathrm{Ni}$ NP exposed cells and decreased following both NiO NPs and to a lower extent $\mathrm{NiCl}_{2}$ exposures, albeit not significantly compared to the untreated control. Taken together, all three Ni exposures significantly induced chromosomal aberrations in the BEAS-2B lung cells.
$\mathrm{Ni}$-induced genome instability and cytotoxicity are calcium- and iron dependent

Finally, we attempted to identify possible underlying mechanisms for the chromosomal damage observed. Given the results showing clear chromosome damage from all three $\mathrm{Ni}$ exposures despite the differences in uptake (no measurable uptake of $\mathrm{NiCl}_{2}$ ), we decided to evaluate mechanisms that are independent on uptake such as effects on calcium signaling and iron metabolism that may be mediated via the plasma membrane or are related to oxidative stress [36]. Co-exposure of BEAS-2B with the iron chelator deferoxamine followed by treatment with $5 \mu \mathrm{g} \mathrm{Ni} / \mathrm{mL}$ of $\mathrm{Ni} / \mathrm{NiO} \mathrm{NPs}$ or $\mathrm{NiCl}_{2}$ significantly reduced the $\mathrm{NiO}$ - and $\mathrm{NiCl}_{2}$-induced increase in $\mathrm{MN}$ to levels near the control value (Fig. $7 \mathrm{a}$ and b) whereas exposure to Ni NPs was less affected. Similar results were also observed for formation of NPB and NBUD (Fig. 7c and d). For the calcium modulators, co-exposure of BEAS-2B with verapamil, an inhibitor of calcium uptake through the plasma membrane, or BAPTA-AM, a cell-permeable $\mathrm{Ca}^{2+}$ chelator, followed by treatment with $5 \mu \mathrm{g} \mathrm{Ni} / \mathrm{mL}$ of $\mathrm{Ni} / \mathrm{NiO} \mathrm{NPs}$ or $\mathrm{NiCl}_{2}$ significantly reverted genotoxicity to control values for all $\mathrm{Ni}$ exposures. Co-treatment with dantrolene, an antagonist of ryanodine (Ry) receptors preventing $\mathrm{Ca}^{2+}$ release from the endoplasmic reticulum (ER), protected against NPs-induced genotoxicity but not the $\mathrm{NiCl}_{2}$-induced genotoxicity (Fig. 7). In addition, similar protective effects were observed for $\mathrm{NiO}$-induced apoptosis and necrosis (Fig. 8a and b).

\section{Discussion}

Despite considerable progress in understanding the toxicological effects of NPs, less is known about their impact at the chromosomal level and underlying mechanisms are poorly understood. In this study, we investigated the ability of $\mathrm{Ni}$ and $\mathrm{NiO}$ NPs to induce DNA and chromosomal damage in BEAS-2B cells and we compared these effects with those of ionic $\mathrm{Ni}$ from soluble $\mathrm{NiCl}_{2}$. To discern the underlying mechanism, we studied cell uptake and explored the role of calcium and iron by using a range of inhibitors and chelators. The results revealed chromosomal damage by $\mathrm{Ni}$ and $\mathrm{NiO} \mathrm{NPs}$ as well as $\mathrm{Ni}$ ionic species and calcium signaling was implicated in this process.

We initially characterized the reactivity of the NPs and found a high intrinsic ROS generating ability of $\mathrm{NiO}$ as also has been shown previously when compared to other metal oxide NPs [37, 38]. ROS was analyzed using DCFH that can be oxidized to fluorescent DCF by hydroxyl radicals and peroxynitrite, as well as by $\mathrm{H}_{2} \mathrm{O}_{2}$ in the presence of peroxidases such as HRP. The high fluorescence observed without HRP for NiO NPs suggests formation of hydroxyl radicals and peroxinitrite, in contrast to Ni NPs only showing activity in the presence 


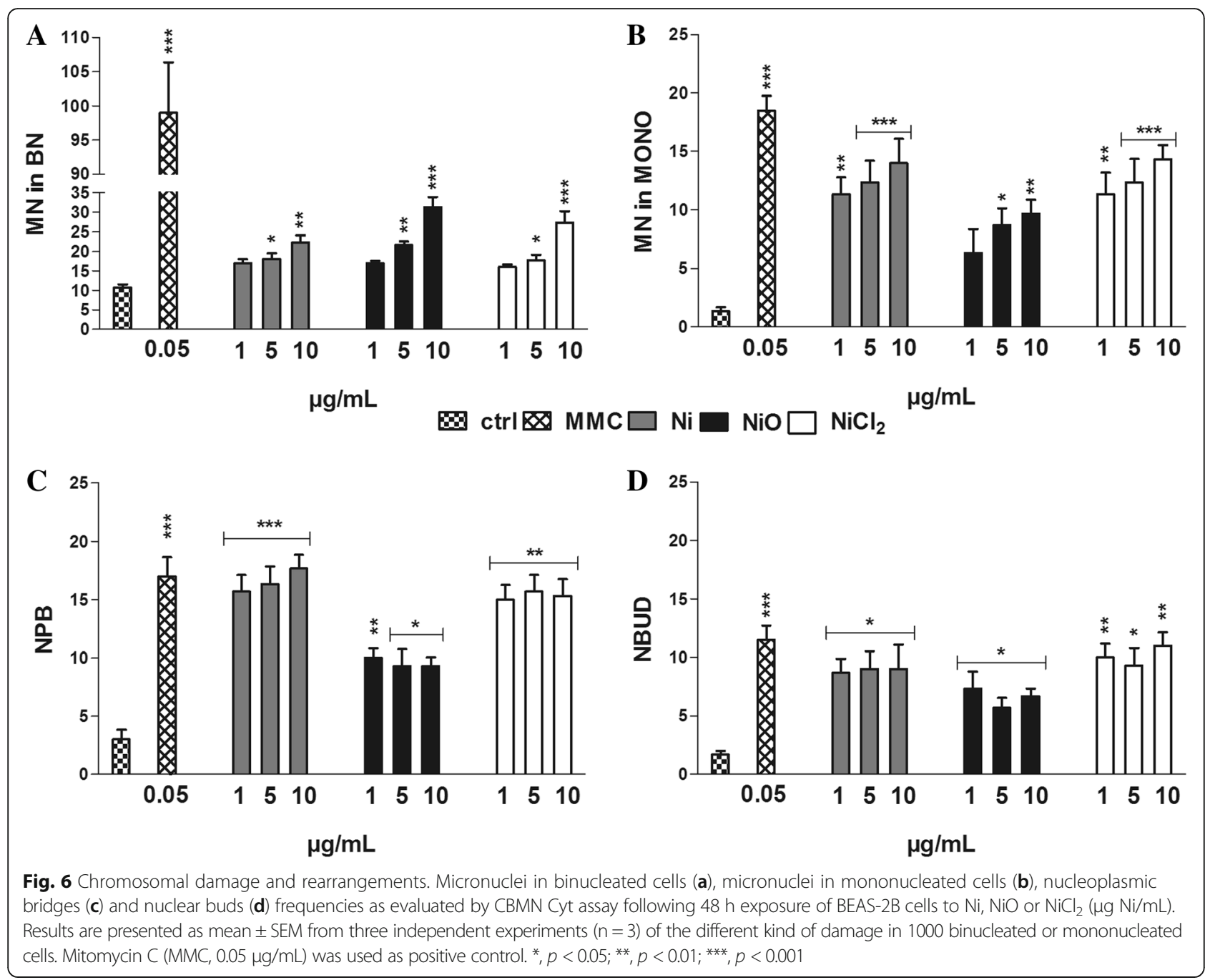

of HRP thus suggesting formation of $\mathrm{H}_{2} \mathrm{O}_{2}$, The ROS production was particle-specific since no effects were observed for ionic Ni. We noted that the NPs agglomerated in cell medium and $\mathrm{Ni}$ was released from both $\mathrm{Ni}$ and $\mathrm{NiO}$ NPs in a time-dependent manner corresponding to approx. $2-9 \%$ of the total mass $\mathrm{Ni}$ after $4-48 \mathrm{~h}$, in line with previous investigations $[22,24]$. The somewhat higher release from $\mathrm{NiO}$ than $\mathrm{Ni}$ is expected and related to the barrier properties of a thin passive surface oxide of the Ni NPs (shell-core structure) of different characteristics compared with the NiO NPs lacking such a surface barrier and metallic core [21, 22]. The higher surface area (BET) for the NiO NPs could also be an explanation since this reflects differences in particle size and/or different porosity at dry conditions. The difference in available surface area will likely be less pronounced in solution since both NPs rapidly agglomerated. Next, we considered the cellular dose of the exposures. The importance of cellular dosimetry of NPs for in vitro toxicity studies is clearly well established [39] and recently, a new model that can be used to estimate delivery of both particles and released ionic species to cells has been developed [40]. However, instead of modeling the dose, we measured the dose, i.e., the NPs taken up or firmly attached to the cells, by using ICP-MS. High uptake was observed for the NPs whereas no clear increase in Ni was observed in cells exposed to $\mathrm{NiCl}_{2}$. The uptake for ionic $\mathrm{Ni}$ is expected to be low, but it has been reported that $\mathrm{Ni}$ ionic species may enter cells via cell membrane transporters, such as the DMT1, or via calcium channels [9]. Despite the apparent lack of uptake of $\mathrm{Ni}$ ions/complexes, an increase in oxidative stress, DNA strand break formation and chromosomal damage was not only observed for the NPs, but also for $\mathrm{NiCl}_{2}$. These findings led us to search for mechanisms that, at least partly, may be explained by interactions with the cell membrane/receptors. Previous studies have shown that $\mathrm{Ni}^{2+}$ ions block calcium channels and $\mathrm{Ni}$ ionic species/complexes have also been found to lead to increased intracellular $\mathrm{Ca}^{2+}$, possibly via a compensatory intracellular release of $\mathrm{Ca}^{2+}$ from intracellular stores [41]. 

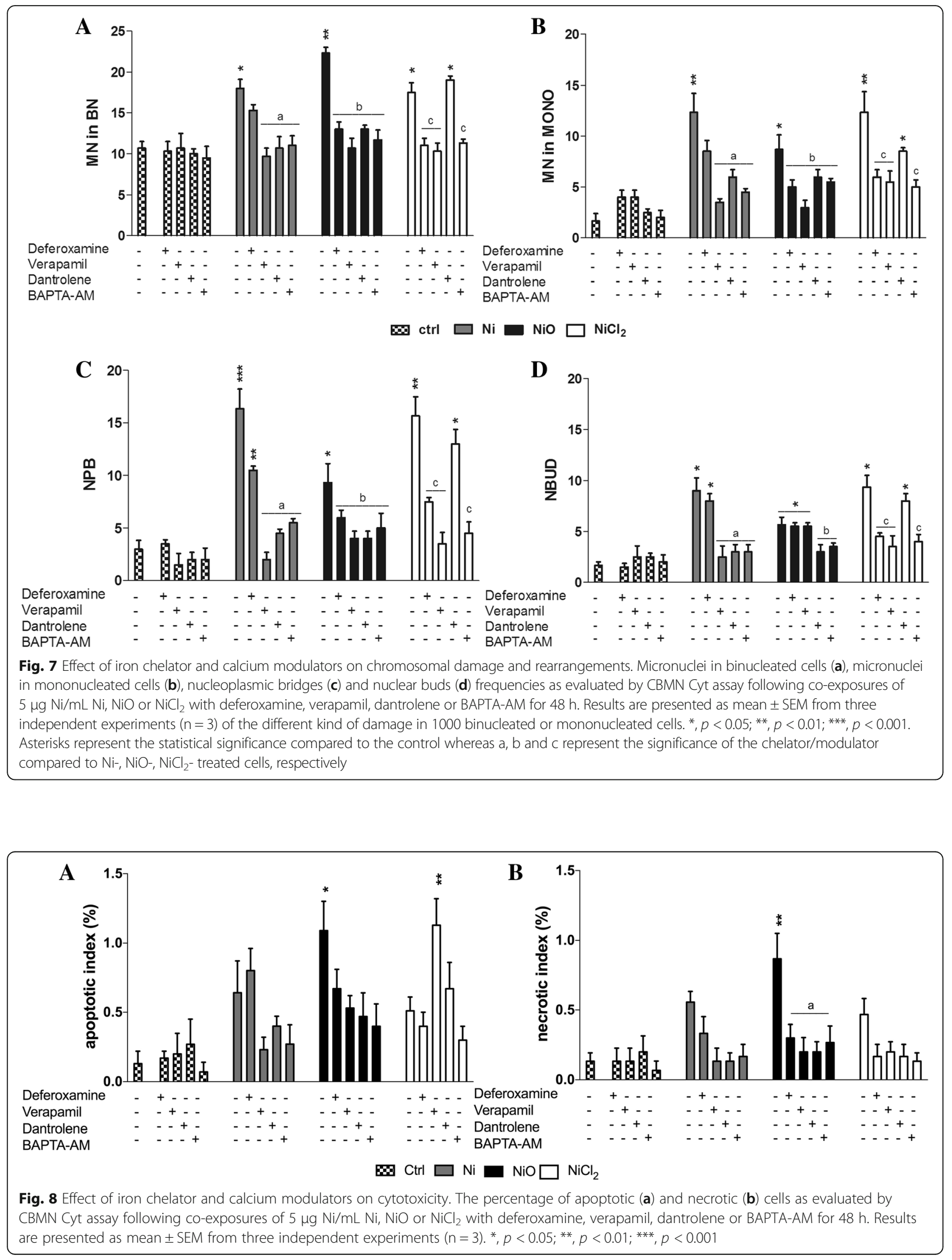
Furthermore, $\mathrm{Ni}$ has been shown to elicit $\mathrm{Ca}^{2+}$-dependent interleukin (IL)-8 gene activation in the human monocytic cell line THP-1, as evidenced by the inhibitory action of the $\mathrm{Ca}^{2+}$ channel inhibitor, nifedipine [42]. The authors speculated on the mechanisms by which divalent cations such as $\mathrm{Ni}^{2+}$ enter cells and suggested that calcium channels may be transducers of Ni due to metal ion 'mimicry'. The involvement of $\mathrm{Ca}^{2+}$ signaling in the present model appeared plausible since we noted an increase in intracellular $\mathrm{Ca}^{2+}$ as a result of the $\mathrm{Ni}$ exposures. To test the involvement of $\mathrm{Ca}^{2+}$ signaling, we employed various modulators of calcium signaling: verapamil, an inhibitor of voltage-dependent $\mathrm{Ca}^{2+}$ channels in the plasma membrane, the intracellular $\mathrm{Ca}^{2+}$ chelator, BAPTA-AM, as well as dantrolene, an antagonist of ryanodine (Ry) receptors in the ER (Fig. 9). We found that all three $\mathrm{Ca}^{2+}$ modulators clearly prevented the chromosomal damage induced by the NPs, thus providing evidence for a role of $\mathrm{Ca}^{2+}$ in the genotoxicity of $\mathrm{Ni} / \mathrm{NiO} \mathrm{NPs}$. However, in the case of $\mathrm{NiCl}_{2}$, dantrolene was not protective, suggesting that release of $\mathrm{Ca}^{2+}$ from intracellular stores was important for the genotoxicity induced by the NPs, but not by $\mathrm{NiCl}_{2}$. Hence, our studies have revealed a particle-specific mechanism, though the final endpoint (chromosomal damage) is not necessarily unique for particles. Other studies have also shown an increase in intracellular $\mathrm{Ca}^{2+}$ following exposure to high doses of soluble green nickel carbonate hydroxide $\left(\mathrm{Ni}_{5}\left(\mathrm{CO}_{3}\right)_{2}(\mathrm{OH})_{6} \cdot 4 \mathrm{H}_{2} \mathrm{O}\right)$ [43] or to other NPs such as CdSe quantum dots [44]. In addition to the effect on $\mathrm{Ca}^{2+}$ modulation, treatment with the iron chelator, deferoxamine was also protective for $\mathrm{NiO} \mathrm{NPs}$ and $\mathrm{NiCl}_{2}$, i.e., the same exposures causing increased intracellular ROS. The protective effect of deferoxamine suggests a mechanism by which Ni triggers increased levels of intracellular iron that may take part in Fenton-like reactions causing oxidative stress and DNA damage. Deferoxamine has previously been suggested to prevent DNA-protein crosslink formation induced by poorly soluble $\mathrm{Ni}_{3} \mathrm{~S}_{2}$ [45]. Furthermore, in studies on lymphocytes exposed to $\mathrm{Ni}_{5}\left(\mathrm{CO}_{3}\right)_{2}(\mathrm{OH})_{6} \cdot 4 \mathrm{H}_{2} \mathrm{O}$, M'Bemba-Meka and co-workers showed a protective effect of both deferoxamine and calcium modulators for the formation of DNA strand breaks and sister-chromatid exchange [46, 47]. In our study, we also found protection from $\mathrm{NiO}$-induced apoptosis and necrosis from all inhibitors/chelators in line with the fact that cellular $\mathrm{Ca}^{2+}$ overload, or perturbation of intracellular $\mathrm{Ca}^{2+}$ compartmentalization, can cause cytotoxicity and trigger either apoptotic or necrotic cell death [48]. Taken together, the current data along with other recent studies suggest the involvement of calcium and iron in the toxicity of soluble $\mathrm{Ni}$ compounds as well as of $\mathrm{Ni}$ and $\mathrm{NiO}$ (nano) particles.

In the nano (geno) toxicological field, a critical question concerns the importance of direct DNA interactions versus non DNA-reactive mechanisms. Using mechanism-specific reporter cell lines, we recently showed that oxidative stress appeared to be a main toxic mechanism of $\mathrm{Ni}$ and $\mathrm{NiO}$ $\mathrm{NPs} /$ ionic Ni species, and none of these exposures induced the reporter related to direct DNA damage and stalled replication forks, indicating that they are not direct DNA reactive [24]. In the current study using BEAS-2B cells, $\mathrm{Ni}$ NPs showed some divergent effects compared to NiO NPs, such as an increased proliferation, in line with previous findings [22], effects similar to aneugen-like spindle poisons, and endoreduplications (duplication of nuclear genome in the absence of cell division). Interestingly, endoreduplications and multinuclear cells as well as disruption of tubulin filaments were recently reported in A549 lung carcinoma cells following exposure to magnetite NPs [49]. In general, interference with the cytoskeleton

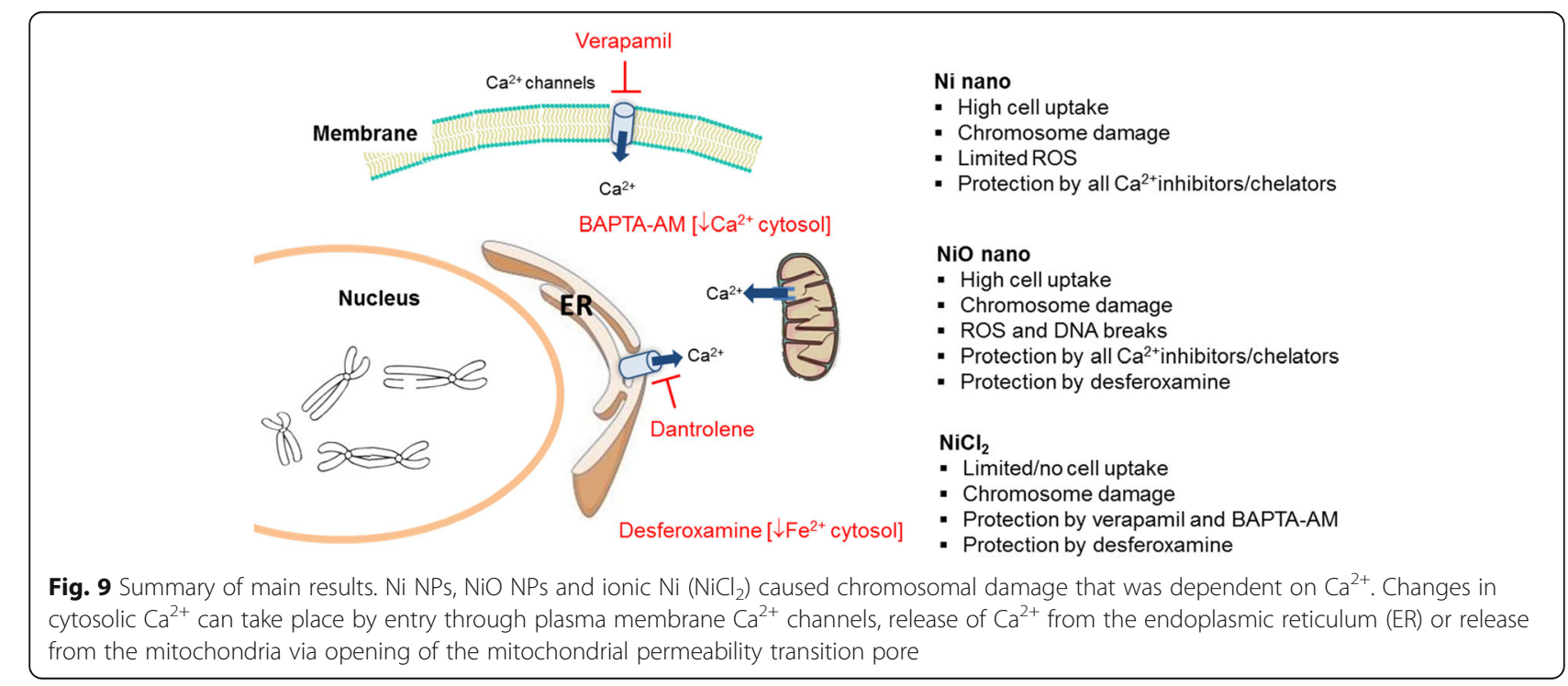


organization/tubulin filaments appears plausible in cells with high content of NPs [50-52]. However, the lack of uptake of $\mathrm{NiCl}_{2}$, as evidenced in the present study, indicates that cell surface proteins/receptors may also be involved, as proposed for $\mathrm{Cd}^{2+}$ (another $\mathrm{Ca}^{2+}$ 'mimetic') [53]. Another receptor that could potentially be involved is TRPV4, a $\mathrm{Ca}^{2+}$ permeable non-selective cation channel that acts as a regulator of both microtubules and actin [54]. Interestingly, silica NPs were recently shown to inhibit TRPV4 activation in cultured human airway epithelial cells 16HBE [55]. Taken together, the involvement of plasma membrane receptors versus intracellular effects in relation to the effects of $\mathrm{Ni}$ and $\mathrm{NiO} \mathrm{NPs}$, as well as $\mathrm{Ni}$ ionic species, need to be explored further. It is also important to note that the toxicological effects for NPs are expected to be more severe than for soluble Ni species, due to higher lung retention. For instance, Shinohara et al. showed recently that after intratracheal administration in rats, $40-60 \%$ of the dose remained in the lungs after 90 days for poorly soluble spherical NiO NPs whereas $<0.3 \%$ remained in case of the soluble $\mathrm{NiO}$ nanowires [56].

\section{Conclusion}

In conclusion, the present study has shown that $\mathrm{Ni}$ and $\mathrm{NiO} \mathrm{NPs}$ as well as Ni ionic species triggered chromosomal damage in a human lung cell line and has provided evidence for a mechanism that does not necessarily require cellular uptake, but depends on the modulation of intracellular calcium and iron. NiO-induced cell death in the present model was also shown to be calcium-dependent.

\section{Additional file}

Additional file 1: Table S1. Chromatid- and chromosome-type aberrations and mitotic index. Figure S1. Apoptotic and Necrotic indices by CBMN Cyt assay. Figure S2. Representative metaphases of BEAS-2B cells (DOCX 267 kb).

\section{Acknowledgements}

The authors gratefully acknowledge Dr. Kjell Hultenby, Karolinska Institutet, for TEM imaging.

\section{Funding}

This study was supported by the Swedish Research Council for Health, Working Life and Welfare (FORTE, project 2011-0832) and the Swedish Research Council (projects 2014-4598 and 2017-03931).

\section{Availability of data and materials}

The datasets used and/or analyzed during the current study are available from the corresponding author on reasonable request.

\section{Authors' contributions}

SDB was involved in the experimental design, performed the majority of the cell culture work (annexinV/PI staining, intracellular ROS, micronucleus assay, chromosome aberrations), compiled the data, and wrote the first version of the manuscript; ARG performed the comet assay and $\mathrm{Ni}$ analysis using ICP-MS; EÅ performed the intrinsic ROS analysis, took part in the cell culture work and performed the analysis of intracellular calcium; SS performed the PCCS analysis; IOW performed the XPS analysis and supervised the particle characterization; BF was involved in data interpretation and manuscript preparation; HLK initiated the study, supervised the cell experiments and was involved in the data interpretation and manuscript preparation; all the authors contributed to the final version of the manuscript. All authors read and approved the final manuscript.

Ethics approval and consent to participate

Not applicable.

\section{Consent for publication}

Not applicable.

\section{Competing interests}

The authors declare that they have no competing interests.

\section{Publisher's Note}

Springer Nature remains neutral with regard to jurisdictional claims in published maps and institutional affiliations.

\section{Author details}

${ }^{1}$ Institute of Environmental Medicine, Karolinska Institutet, Stockholm, Sweden. ${ }^{2}$ KTH Royal Institute of Technology, Department of Chemistry, Surface and Corrosion Science, Stockholm, Sweden.

Received: 19 March 2018 Accepted: 29 June 2018

Published online: 17 July 2018

References

1. Zhao J, Shi X, Castranova V, Ding M. Occupational toxicology of nickel and nickel compounds. J Environ Pathol Toxicol Oncol. 2009;28:177-208.

2. Klein A, Costa M. Nickel and nickel compounds. In: Handbook on the toxicology of metals. 4th ed; 2014.

3. IARC. Chromium, nickel and welding. In: IARC monographs volume 49; 1990.

4. IARC. Arsenic, metals, fibres, and dusts. In: IARC monographs volume 100C; 2012.

5. Oller AR, Kirkpatrick DT, Radovsky A, Bates HK. Inhalation carcinogenicity study with nickel metal powder in Wistar rats. Toxicol Appl Pharmacol. 2008;233:262-75.

6. Guha N, Loomis D, Guyton KZ, Grosse Y, El Ghissassi F, Bouvard V, et al. Carcinogenicity of welding, molybdenum trioxide, and indium tin oxide. Lancet Oncol. 2017;18:581-2.

7. Schaumloffel D. Nickel species: analysis and toxic effects. J Trace Elem Med Biol. 2012;26:1-6.

8. Oller AR, Costa M, Oberdorster G. Carcinogenicity assessment of selected nickel compounds. Toxicol Appl Pharmacol. 1997;143:152-66.

9. Munoz A, Costa M. Elucidating the mechanisms of nickel compound uptake: a review of particulate and nano-nickel endocytosis and toxicity. Toxicol Appl Pharmacol. 2012;260:1-16.

10. Oller AR. Respiratory carcinogenicity assessment of soluble nickel compounds. Environ Health Perspect. 2002;110(Suppl 5):841-4.

11. Goodman JE, Prueitt RL, Thakali S, Oller AR. The nickel ion bioavailability model of the carcinogenic potential of nickel-containing substances in the lung. Crit Rev Toxicol. 2011;41:142-74.

12. Imran Din M, Rani A. Recent advances in the synthesis and stabilization of nickel and nickel oxide nanoparticles: a green adeptness. Int J Anal Chem. 2016;2016:3512145.

13. Journeay WS, Goldman RH. Occupational handling of nickel nanoparticles: a case report. Am J Ind Med. 2014;57:1073-6.

14. Phillips JI, Green FY, Davies JC, Murray J. Pulmonary and systemic toxicity following exposure to nickel nanoparticles. Am J Ind Med. 2010;53:763-7.

15. Cho WS, Duffin R, Poland CA, Howie SE, MacNee W, Bradley M, et al. Metal oxide nanoparticles induce unique inflammatory footprints in the lung: important implications for nanoparticle testing. Environ Health Perspect. 2010;118:1699-706.

16. Cho WS, Duffin R, Bradley M, Megson IL, Macnee W, Howie SE, et al. NiO and Co3O4 nanoparticles induce lung DTH-like responses and alveolar lipoproteinosis. Eur Respir J. 2012;39:546-57.

17. Ogami A, Morimoto Y, Myojo T, Oyabu T, Murakami M, Todoroki M, et al. Pathological features of different sizes of nickel oxide following intratracheal instillation in rats. Inhal Toxicol. 2009;21:812-8.

18. Horie M, Nishio K, Fujita K, Kato H, Nakamura A, Kinugasa S, et al. Ultrafine $\mathrm{NiO}$ particles induce cytotoxicity in vitro by cellular uptake and subsequent Ni (II) release. Chem Res Toxicol. 2009;22:1415-26. 
19. Pietruska JR, Liu X, Smith A, McNeil K, Weston P, Zhitkovich A, et al. Bioavailability, intracellular mobilization of nickel, and HIF-1alpha activation in human lung epithelial cells exposed to metallic nickel and nickel oxide nanoparticles. Toxicol Sci. 2011;124:138-48.

20. Magaye R, Gu Y, Wang Y, Su H, Zhou Q, Mao G, et al. In vitro and in vivo evaluation of the toxicities induced by metallic nickel nano and fine particles. J Mol Histol. 2016;47:273-86.

21. Mazinanian N, Hedberg Y, Odnevall Wallinder I. Nickel release and surface characteristics of fine powders of nickel metal and nickel oxide in media of relevance for inhalation and dermal contact. Regul Toxicol Pharmacol. 2013;65:135-46.

22. Latvala S, Hedberg J, Di Bucchianico S, Moller L, Odnevall Wallinder I, Elihn $\mathrm{K}$, et al. Nickel release, ROS generation and toxicity of $\mathrm{Ni}$ and $\mathrm{NiO}$ microand nanoparticles. PLoS One. 2016;11:e0159684.

23. Kasprzak KS, Sunderman FW Jr, Salnikow K. Nickel carcinogenesis. Mutat Res. 2003;533:67-97

24. Åkerlund E, Cappellini F, Di Bucchianico S, Islam S, Skoglund S, Derr R, et al. Genotoxic and mutagenic properties of $\mathrm{Ni}$ and $\mathrm{NiO}$ nanoparticles investigated by comet assay, gamma-H2AX staining, Hprt mutation assay and ToxTracker reporter cell lines. Environ Mol Mutagen. 2018;59:211-22.

25. Courcot E, Leclerc J, Lafitte JJ, Mensier E, Jaillard S, Gosset P, et al. Xenobiotic metabolism and disposition in human lung cell models: comparison with in vivo expression profiles. Drug Metab Dispos. 2012;40:1953-65.

26. Gonzalez L, Sanderson BJ, Kirsch-Volders M. Adaptations of the in vitro MN assay for the genotoxicity assessment of nanomaterials. Mutagenesis. 2011;26:185-91.

27. Golbamaki N, Rasulev B, Cassano A, Marchese Robinson RL, Benfenati E, Leszczynski J, et al. Genotoxicity of metal oxide nanomaterials: review of recent data and discussion of possible mechanisms. Nano. 2015;7:2154-98.

28. Gliga AR, Skoglund S, Odnevall Wallinder I, Fadeel B, Karlsson HL. Sizedependent cytotoxicity of silver nanoparticles in human lung cells: the role of cellular uptake, agglomeration and ag release. Part Fibre Toxicol. 2014;11:11.

29. Jitkaew S, Trebinska A, Grzybowska E, Carlsson G, Nordstrom A, Lehtio J, et al. N (alpha)-tosyl-L-phenylalanine chloromethyl ketone induces caspasedependent apoptosis in transformed human B cell lines with transcriptional down-regulation of anti-apoptotic HS1-associated protein X-1. J Biol Chem. 2009:284:27827-37.

30. Fenech M. Cytokinesis-block micronucleus cytome assay. Nat Protoc. 2007;2:1084-104.

31. Di Bucchianico S, Fabbrizi MR, Cirillo S, Uboldi C, Gilliland D, Valsami-Jones $E$, et al. Aneuploidogenic effects and DNA oxidation induced in vitro by differently sized gold nanoparticles. Int J Nanomedicine. 2014;9:2191-204.

32. Rosefort C, Fauth E, Zankl H. Micronuclei induced by aneugens and clastogens in mononucleate and binucleate cells using the cytokinesis block assay. Mutagenesis. 2004;19:277-84.

33. Nymark P, Catalan J, Suhonen S, Jarventaus H, Birkedal R, Clausen PA, et al. Genotoxicity of polyvinylpyrrolidone-coated silver nanoparticles in BEAS 2B cells. Toxicology. 2013;313:38-48.

34. Grosvenor AP, Biesinger MC, Smart RSC, Mclntyre NS. New interpretations of XPS spectra of nickel metal and oxides. Surf Sci. 2006;600:1771-9.

35. Biesinger MC, Payne BP, Grosvenor AP, Lau LWM, Gerson AR, Smart RSC. Resolving surface chemical states in XPS analysis of first row transition metals, oxides and hydroxides: $\mathrm{Cr}, \mathrm{Mn}, \mathrm{Fe}, \mathrm{Co}$ and $\mathrm{Ni}$. Appl Surf Sci. 2011;257:2717-30.

36. Orrenius S, Nicotera P, Zhivotovsky B. Cell death mechanisms and their implications in toxicology. Toxicol Sci. 2011;119:3-19.

37. Lu S, Duffin R, Poland C, Daly P, Murphy F, Drost E, et al. Efficacy of simple short-term in vitro assays for predicting the potential of metal oxide nanoparticles to cause pulmonary inflammation. Environ Health Perspect. 2009;117:241-7.

38. Karlsson HL, Gliga AR, Calleja FM, Goncalves CS, Odnevall Wallinder I, Vrieling $\mathrm{H}$, et al. Mechanism-based genotoxicity screening of metal oxide nanoparticles using the ToxTracker panel of reporter cell lines. Part Fibre Toxicol. 2014;11:41.

39. Cohen JM, Teeguarden JG, Demokritou P. An integrated approach for the in vitro dosimetry of engineered nanomaterials. Part Fibre Toxicol. 2014;11:20.

40. Thomas DG, Smith JN, Thrall BD, Baer DR, Jolley H, Munusamy P, et al. ISD3: a particokinetic model for predicting the combined effects of particle sedimentation, diffusion and dissolution on cellular dosimetry for in vitro systems. Part Fibre Toxicol. 2018;15:6.
41. Cortijo J, Milara J, Mata M, Donet E, Gavara N, Peel SE, et al. Nickel induces intracellular calcium mobilization and pathophysiological responses in human cultured airway epithelial cells. Chem Biol Interact. 2010;183:25-33.

42. Lin $\mathrm{CH}$, Chung CA, Wong JH, Chen BK, Chiu SJ, Klahan S, et al. Involvement of L-type ca (2) (+) channel and toll-like receptor-4 in nickel-induced interleukin-8 gene expression. Environ Toxicol. 2016;31:5-12.

43. M'Bemba-Meka P, Lemieux N, Chakrabarti SK. Role of oxidative stress, mitochondrial membrane potential, and calcium homeostasis in human lymphocyte death induced by nickel carbonate hydroxide in vitro. Arch Toxicol. 2006;80:405-20.

44. Tang M, Wang M, Xing T, Zeng J, Wang H, Ruan DY. Mechanisms of unmodified CdSe quantum dot-induced elevation of cytoplasmic calcium levels in primary cultures of rat hippocampal neurons. Biomaterials. 2008;29:4383-91.

45. Chakrabarti SK, Bai C, Subramanian KS. DNA-protein crosslinks induced by nickel compounds in isolated rat lymphocytes: role of reactive oxygen species and specific amino acids. Toxicol Appl Pharmacol. 2001;170:153-65.

46. M'Bemba-Meka P, Lemieux N, Chakrabarti SK. Nickel compound-induced DNA single-strand breaks in chromosomal and nuclear chromatin in human blood lymphocytes in vitro: role of oxidative stress and intracellular calcium. Mutat Res. 2005:586:124-37.

47. M'Bemba-Meka P, Lemieux N, Chakrabarti SK. Role of oxidative stress and intracellular calcium in nickel carbonate hydroxide-induced sister-chromatid exchange, and alterations in replication index and mitotic index in cultured human peripheral blood lymphocytes. Arch Toxicol. 2007:81:89-99.

48. Orrenius S, Zhivotovsky B, Nicotera P. Regulation of cell death: the calciumapoptosis link. Nat Rev Mol Cell Biol. 2003:4:552-65.

49. Buliakova B, Mesarosova M, Babelova A, Selc M, Nemethova V, Sebova L, et al. Surface-modified magnetite nanoparticles act as aneugen-like spindle poison. Nanomedicine. 2017;13:69-80.

50. Gliga AR, Edoff $K$, Caputo F, Kallman T, Blom H, Karlsson HL, et al. Cerium oxide nanoparticles inhibit differentiation of neural stem cells. Sci Rep. 2017;7:9284

51. Garcia-Hevia L, Valiente R, Martin-Rodriguez R, Renero-Lecuna C, Gonzalez J, Rodriguez-Fernandez $\mathrm{L}$, et al. Nano-ZnO leads to tubulin macrotube assembly and actin bundling, triggering cytoskeletal catastrophe and cell necrosis. Nano. 2016;8:10963-73.

52. Ma X, Hartmann R, Jimenez de Aberasturi D, Yang F, Soenen SJH, Manshian $\mathrm{BB}$, et al. Colloidal gold nanoparticles induce changes in cellular and subcellular morphology. ACS Nano. 2017;11:7807-20.

53. Choong G, Liu Y, Templeton DM. Interplay of calcium and cadmium in mediating cadmium toxicity. Chem Biol Interact. 2014;211:54-65.

54. Goswami C, Kuhn J, Heppenstall PA, Hucho T. Importance of non-selective cation channel TRPV4 interaction with cytoskeleton and their reciprocal regulations in cultured cells. PLoS One. 2010;5:e11654.

55. Sanchez A, Alvarez JL, Demydenko K, Jung C, Alpizar YA, Alvarez-Collazo J, et al. Silica nanoparticles inhibit the cation channel TRPV4 in airway epithelial cells. Part Fibre Toxicol. 2017;14:43

56. Shinohara N, Zhang G, Oshima Y, Kobayashi T, Imatanaka N, Nakai M, et al. Kinetics and dissolution of intratracheally administered nickel oxide nanomaterials in rats. Part Fibre Toxicol. 2017:14:48.

\section{Ready to submit your research? Choose BMC and benefit from:}

- fast, convenient online submission

- thorough peer review by experienced researchers in your field

- rapid publication on acceptance

- support for research data, including large and complex data types

- gold Open Access which fosters wider collaboration and increased citations

- maximum visibility for your research: over $100 \mathrm{M}$ website views per year

At BMC, research is always in progress.

Learn more biomedcentral.com/submissions 